\title{
TOWARZYSTWO NAUKOWE KRAKOWSKIE I AKADEMIA UMIEJECTNOŚCI W BADANIACH BOTANICZNYCH TATR DO ROKU 1914
}

\section{ZARYS PROBLEMATYKI}

Badania botaniczne prowadzone w Tatrach, przede wszystkim na stokach północnych, położonych po polskiej stronie pasma, z inspiracji Towarzystwa Naukowego Krakowskiego, a później Akademii Umiejętności imponują wielkością i zakresem tematycznym. Zagadnienie to winno stać się tematem obszernej pracy monograficznej, chociażby ze względu na wielki wkład obu krakowskich instytucji w dzieło naukowego poznania najwyższego pasma Karpat. Niniejszy artykuł stanowi historyczny zarys poruszanej problematyki i nie wyczerpuje całości zagadnienia. Przyjęto w nim układ tematyczno-chronologiczny.

\section{FLORYSTYKA}

Tak jak w przypadku innych pasm Karpat, zarówno Wschodnich, jak i Zachodnich, badania botaniczne koncentrowały się głównie na pracach z zakresu florystyki ${ }^{1}$. W drugim tomie Sprawozdań Komisji Fizyograficznej (dalej w tekście jako SKF) Wojciech Grzegorzek wyróżnił kilkadziesiąt gatunków roślin, m.in. z Tatr i Podhala ${ }^{2}$. Do artykułu tego ustosunkował się krytycznie Antoni Reh-

${ }^{1}$ Na temat badań botanicznych Akademii Umiejętności: J. Dybiec, Polska Akademia Umiejętności 1872-1952, Kraków 1993; P. Köhler, Botanika w Towarzystwie Naukowym Krakowskim, Akademii Umiejętności i Polskiej Akademii Umiejętności (1815-1952). Studia i materiały do dziejów Polskiej Akademii Umiejętności, t. 2, PAU, Kraków 2002; tegoż, Bibliografia botaniki w Towarzystwie Naukowym Krakowskim, Akademii Umiejętności i Polskiej Akademii Umiejętności, PAN, Kraków 2004; A. Zemanek, Bibliografia botaniki na Uniwersytecie Jagiellońskim 1532-1917, Uniwersytet Jagielloński - varia 251, Kraków 1988; tejże, Historia botaniki na Uniwersytecie Jagiellońskim (17801917), Kraków 1989.

2 W. Grzegorzek, Spis roślin w różnych okolicach Galicyi zebranych, „Sprawozdanie Komisyi Fizyograficznej" (dalej: SKF), SKF 2: 1868, s. (34)-(50). 
$\operatorname{man}^{3}$. Istniały spore rozbieżności, co do rozmieszczenia wielu gatunków, których stanowiska w Galicji, na podstawie dotychczasowych badań, były bardzo wątpliwe. Tak było w przypadku gatunku z rodzaju selerowatych przewiercień długolistny (Bupleurum longifolium L.), mającego wg Grzegorzka występować w okolicach Tarnopola, czy stepowej Trinia vulgaris DC. na Hali Pysznej w Tatrach. Mając to na uwadze, Komisja Fizjograficzna zwróciła się do Grzegorzka o przesłanie okazów 45 gatunków, których sprawdzenie uznała za pożądane. Ten przesłał 38 gatunków, które następnie przekazano Rehmanowi, aby sprostował błędnie oznaczone.

Eugeniusz Janota w drugiej połowie czerwca 1877 r. badał florę Pienin, Czorsztyna i Zakopanego, a w lipcu i drugiej połowie sierpnia - Tatr. Odbył cztery większe wycieczki i kilkanaście mniejszych. Po powrocie do Lwowa, mimo nie najlepszego stanu zdrowia, zajął się przygotowaniem do oznaczania zebranych roślin tatrzańskich i porządkowaniem zebranego zielnika. Efektem było przesłanie w październiku 1877 r. zielnika do zbiorów Komisji Fizjograficznej Akademii Umiejętności (dalej jako Komisja), obejmującego 1 tys. gatunków i ponad 3 tys. okazów. W liście do przewodniczącego Komisji z 19 marca 1878 r. pisał: „na przyszły tydzień zabiorę się do ukończenia już rozpoczętego i prawie do połowy doprowadzonego ułożenia roślin tatrzańskich zeszłorocznych i napisania sprawozdania [...] sprawozdanie będzie dokładne, mam bowiem na miejscu robione zapiski" ${ }^{4}$. Niestety brak czasu i pogarszający się stan zdrowia, a wreszcie przedwczesna śmierć nie pozwoliły na dokończenie pracy. Jeszcze 16 czerwca przesłał Komisji 310 gatunków i 1244 okazy roślin tatrzańskich i pienińskich, jednakże tylko częściowo oznaczonych.

Marian Raciborski w 1887 r. badał pod względem florystycznym tereny od granicy spiskiej po Orawę, pas skałek wapiennych od Czorsztyna po Rogoźnik i piaskowce od Mszany na północy po Gubałówkę. W opublikowanym artykule podał 7 gatunków i odmian z Tatr ${ }^{5}$. W tymże roku, 29 października na posiedzeniu Sekcji Botanicznej, przedstawił pracę $O$ osobliwych formach modrzewia $i$ bagna (Ledum palustre var. decumbens Pursch.) na Podhalu ${ }^{6}$. Inne gatunki wymienił w kolejnej pracy, która była oparta na materiale zielnikowym ze zbiorów Komisji oraz zielników: polskiego i ogólnego Muzeum Botanicznego UJ, Władysława Kulczyńskiego, Franciszka Bieniasza ponadto własnego ${ }^{7}$. W następnej publikacji zaprezentował monografię gatunków klonów występujących na ziemiach polskich. Z Tatr i Podhala przytoczył klon jawor (Acer pseudoplatanus L.), drzewa z rodziny mydleńcowatych

\footnotetext{
${ }^{3}$ A. Rehman, Kilka sprostowań do spisu roślin Wojciecha Grzegorzka, SKF 3: 1869, s. (66)(68).

${ }^{4}$ SKF 12: 1878, s. 7; ,Rozprawy Akademii Umiejętności” (dalej jako: RAU) 1877, Kraków 1878, s. 123.

${ }^{5}$ M. Raciborski, Zapiski florystyczne. Cz. 2, SKF XXII: 1888, s. 123-137; RAU 1891, Kraków 1892, s. 96.

${ }^{6}$ SKF 22: 1888, s. 5-6.

7 M. Raciborski, Conspectus funcacearum Poloniae, SKF XXII: 1888, s. 151-180.
} 
(Sapindaceae) $)^{8}$ W latach następnych kontynuował badania florystyczne na Podhalu, szczególnie na obszarze nowotarskim ${ }^{9}$.

W tym samym roku Antoni Rogalski i Ignacy Szyszyłowicz badali rośliny naczyniowe Tatrach Spiskich, podając 538 gatunków. Analiza tekstu pokazuje m.in. istniejące różnice $\mathrm{w}$ nomenklaturze nazw geograficznych w Tatrach, stosowanych dawniej i współcześnie ${ }^{10}$.

Najszerszy opis roślin naczyniowych występujących w Tatrach przedstawił Bolesław Kotula w swej monumentalnej monografii ${ }^{11}$. Badania prowadził w latach 1879-1885, łącznie spędzając w tym paśmie ponad 6 miesięcy, głównie w terminach pomiędzy 13 lipca a 28 sierpnia, stąd nie miał możności wszechstronnego poznania flory tatrzańskiej. Podany przez autora podział Tatr na pasma roślinne nie jest stosowany w dniu dzisiejszym.

Bardzo szeroki zasięg terytorialny miały wieloletnie badania florystyczne Eustachego Wołoszczaka. Często prace terenowe przebiegały w bardzo ciężkich warunkach atmosferycznych, czego dowodzą słowa uczonego: „nadzwyczaj słotna pora wpłynęła niestety niekorzystnie na przebieg badań, a stwierdzenie zapatrywań na związek sąsiednich Karpat z Tatrami co do roślinności, jakie się nasunęly, wymagać będzie jeszcze dalszych poszukiwań" ${ }^{12}$. W Tatrach uczony przebywał jeden dzień w końcu sierpnia 1895 r. $^{13}$

Antoni Józef Żmuda prowadził badania botaniczne w Tatrach i na Podhalu na początku XX w. Miały one na celu uzupełnienie materiału do mającej się ukazać „Flory Polskiej”, stąd zwracał szczególną uwagę na rodzaje złożone z licznych i zmiennych gatunków ${ }^{14}$. Badał okazy pod względem geologicznym i morfologicznym, znajdując nowe dla flory tatrzańskiej gatunki i odmiany byliny z rodzaju ciborowatych, turzycy patagońskiej (Corex magellanica Lam. = Carex paupercula Michx.) i krzewu należącego do rodziny brzozowatych olsza zielona (kosa olcha) (Alnus viridis. Chaix. DC. in Lam. \& DC.) ${ }^{15}$. Badał także florę posłonek (Helianthemum Mill.) na obszarze Sudetów i Karpat. Tylko w Tatrach występował posłonek siwy Helianthemum canum (L.) Baumg ${ }^{16}$. Podano klucz do oznaczania gatunków.

${ }^{8}$ M. Raciborski, Klony polskie, SKF XXIII: 1889, s. 50-55.

${ }^{9}$ SKF 27: 1892, s. 5.

${ }^{10}$ A. Rogalski, Wykaz roślin naczyniowych zebranych przez Dra A. Rogalskiego i J. Szyszytowicza w Spiskich Tatrach wapiennych w 1878 r., SKF XV: 1881, s. 169-205; RAU 1878, Kraków 1879, s. 168; RAU 1879, Kraków 1880, s. 76; RAU 1880, Kraków 1881, s. 104-105.

${ }^{11}$ B. Kotula, Rozmieszczenie roślin naczyniowych $w$ Tatrach (Distributio plantarum vasculosarum in montibus Tatricis), Kraków 1889-1890, ss. 512; RAU 1888, Kraków 1889, s. 118.

${ }_{12}$ SKF 32: 1897, s. IV-V.

${ }^{13}$ E. Wołoszczak, O roślinności karpackiej między Dunajcem i granica Ślaska, SKF 32: 1897, s. 1. Całość tekstu: s. 1-45; RAU 1896/1897, Kraków 1897, s. 83.

${ }^{14}$ SKF 45: 1910, s. X; SKF 46: 1911, s. IX.

15 Według nowszych ujęć taksonomicznych prawidłowa nazwa to Alnus alnobetula subsp. Alnobetula.

${ }^{16}$ A. J. Żmuda, Postonki polskie (Heliantthema Poloniae), „Rozprawy Wydziału Matematyczno-Przyrodniczego" (dalej jako: RWMP) 55: 1916, ser. B, s. 21-35. Prace referował na posiedzeniu Wydziału Mat.-Przyr. M. Raciborski 21 maja 1915 r. 
Kolejne badania dotyczyły przywrotników (Alchemilla) ${ }^{17}$. Żmuda opracował je na podstawie zielników krakowskich: Komisji Fizjograficznej, Instytutu Botaniki UJ, prof. Mariana Raciborskiego oraz własnych materiałów zebranych podczas prac terenowych. Uczony zdawał sobie sprawę, że są to materiały niekompletne. Nie wszystkie gatunki rosnące w Europie środkowej występowały na ziemiach polskich, np. pospolity w Alpach przywrotnik alpejski Alchemilla alpina L. Z kolei duża liczba gatunków, znanych dotychczas tylko z Alp, występowała w Karpatach dosyć pospolicie, w niezmienionej postaci. Jak zorientował się uczony, charakterystyczny dla Karpat, w tym także dla Tatr, był brak różnych gatunków z pospolitej w Europie środkowej grupy Alchemilla coriacea Buser. Żmuda podał gatunki występujące w Sudetach i Karpatach, dla Tatr charakterystyczne były tylko tam występujące Alchemilla firma (Buser. = Alchemilla glaberrima (Buser) Gams. i przywrotnik kosmaty Alchemilla pubescens auct. (=Alchemilla glaucensces Wallr.). Kolejne badania dotyczyły polskich gatunków goryczki (Gentiana) ${ }^{18}$. Żmuda przeprowadził rewizję ich gatunków na podstawie zbiorów krakowskich materiałów zielnikowych. $\mathrm{Na}$ ziemiach polskich występowało 25 gatunków goryczki, przeważnie górskich, stąd znaczna ich część rosła wyłącznie w Karpatach, a tylko cztery występowały na terenie całego kraju. Wyłącznie w Tatrach występowały: goryczka przeźroczysta Gentiana firgida H., goryczka krótkołodygowa G. clusii Perr. i goryczka lodnikowa $G$. Tenella Rattb. Zaprezentowano opisy poszczególnych gatunków. Rewizja przeprowadzona przez autora dostarczyła materiału do poprawienia niektórych granic zasięgów występowania. Uczony zajmował się także świerzbnicami (Knautia), roślinami należącymi do rodziny szczeciowatych (Dipsacaceae Juss.) i ich rozmieszczeniem ${ }^{19}$. Tak jak w poprzednim przypadku materiał badawczy pochodził z krakowskich zielników. Na ziemiach polskich występowało pięć gatunków tej rośliny. Świerzbnica karpacka Knautia kitaibelli (Schult.) Borbás występowała w Tatrach. Podano klucz do oznaczania gatunków.

Rozmieszczeniem i biologią świerka (Picea albies L.) w Tatrach zajmował się Kazimierz Rouppert ${ }^{20}$. Sosny z kolei stały się przedmiotem studiów Edwarda Lubicz-Niezabitowskiego ${ }^{21}$. Osiadły od kilku lat na Podhalu Niezabitowski przedsta-

${ }^{17}$ A. J. Żmuda, Przywrotniki (Alchemilla L.) polskie, RWMP 55: 1916, ser. B, s. 1-20; RAU 1914/1916, Kraków 1916, s. 42. Pracę tę referował na posiedzeniu Wydz. Mat.-Przyr. M. Raciborski 21 maja 1915 r. (druga referowana praca Żmudy, patrz wyżej).

${ }^{18}$ A. J. Żmuda, Polskie gatunki goryczki (Gentiana L.), RWMP 56: 1917, ser. B, s. 121-151; „Sprawozdania z Czynności i Posiedzeń Akademii Umiejętności w Krakowie” (dalej jako: „Sprawozdania”). T. XXI, czerwiec 1916. Nr 6, s. 52; RAU 1916/1917, Kraków 1917, s. 34. Praca ta była referowana na posiedzeniu Wydz. Mat.-Przyr. 5 czerwca 1916 r. przez M. Raciborskiego.

${ }^{19}$ A. J. Żmuda, Świerzbnice (Knautia Coult.) polskie, RWMP 56: 1917, ser. B, s. 219-240; „Sprawozdania”. T. XXI, lipiec 1916. Nr 7, s. 39.

${ }^{20}$ K. Rouppert, Świerk kolumnowy w Tatrach, „Sylwan” 29: 1911, nr 1, s. 1-4. Popularny zarys flory tatrzańskiej i zarys historii jej poznawania: Obraz flory Tatr, „Ziemia” 4: 1913, nr 4, (streszczenie referatu).

${ }^{21}$ E. Lubicz-Niezabitow ski, Materiaty do flory sosen Galicyi, RWMP 49: 1910, ser, B, s. 155184. Pracę tę przedstawił M. Raciborski na posiedzeniu Wydziału Mat.-Przyr. 7 czerwca 1909 r. 
wił rozgraniczenie zasięgu występowania sosny górskiej, czyli kosodrzewiny (Pinus montana Mill.) i sosny zwyczajnej (Pinus silvestris L.) oraz ich stanowiska. Podał morfologię szyszek, na ich podstawie wyodrębnił podział gatunkowy. Stwierdził siedem form sosny górskiej. Formy tatrzańskie różniły się od alpejskich mniejszym rozmiarem szyszek. Rouppert informował także o lokalnych torfowiskach.

\section{BRIOLOGIA}

Pionierski charakter w botanice polskiej ma praca $O$ mchach $i$ watrobowcach Galicyi zachodniej $i$ stosunku ich do ogółu roślinności Antoniego Rehmana ${ }^{22}$. Wyodrębnił piętra wysokościowe w Tatrach, nazywając je krainami, przy opisach mchów i wątrobowców tatrzańskich. Przedstawiono charakterystykę krain geobotanicznych Małopolski i Karpat, ze szczególnym uwzględnieniem udziału mszaków w poszczególnych zbiorowiskach roślinnych. Po raz pierwszy w polskiej literaturze botanicznej ukazane zostało rozmieszczenie pionowe mszaków w Tatrach, wraz z oryginalnym schematem uwzględniającym gatunki typowe dla poszczególnych pięter roślinności Tatr, Babiej Góry i Beskidów ${ }^{23}$.

Mimo pogody niesprzyjającej prowadzeniu badań terenowych w r. 1877 Józef Krupa zajmował się mchami i wątrobowcami w Tatrach ${ }^{24}$. Także krótki czas badań nie pozwolił na przedstawienie kompletnych spostrzeżeń. Podał 207 gatunków. Kolejna publikacja stanowiła uzupełnienie wcześniejszych badań prowadzonych w Tatrach w 1877 r. i rok później na Żywiecczyźnie oraz, w mniejszym zakresie, na innych obszarach Galicji (m.in. okolice Krakowa, Sądecczyzna). Z Tatr podał ponad 269 gatunków, nie wszystkie jednak zamieszczone w spisie miały zaznaczone stanowiska $^{25}$.

Krupa kontynuował badania w następnych latach ${ }^{26}$, m.in. w 1885 r. w paśmie Gubałówki, Palenicy, lasach nowotarskich, Czarnym Dunajcu i na pogórzu babiogórskim. Podhale badał głównie w celu określenia stosunku pomiędzy miejscową florą briologiczną a florą Tatr. Pod tym względem przede wszystkim zwracał uwagę na pasmo Gubałówki oraz Magurę. Zaobserwował szczególnie liczne występowanie na bardziej suchych stanowiskach mchu różnolist dwoistolistny (Heterocladium dimorphum (Bird.) Schimp. = Heterocladium squarrulosum Lind.). Bogato występowały także - jak zauważył - gatunki z rodzaju Hylocomium, zwłaszcza rzadsze, jak gajnik H. pyrenaicum Spruce (Lind.), H. loreum Hedw. (Schimp.) i gajniczek krótkodzióbkowy (Loeskeobryum brevirostre (Brid.) Fleisch. $=$ H. brevirostre (Erh.) Br. eur.). Jeśli chodzi o bory nowotarskie, to stwierdził występowanie na torfowi-

22 A. Rehman, O mchach i watrobowcach Galicyi zachodniej i stosunku ich do ogótu roślinności, „Roczniki Towarzystwa Naukowego Krakowskiego” 31: 1864, 3 (8), s. 257-312.

23 A. Zemanek, B. Zemanek, Wkład Antoniego Rehmana (1840-1917) w rozwój polskiej geografii roślin, „Kwartalnik Historii Nauki i Techniki” 1991, 36/2, s. 56.

${ }^{24}$ J. Krupa, Wykaz mchów zebranych $w$ Tatrach $w$ sierpniu 1877 roku, SKF 12: 1878, s. (149)(161).

25 SKF 16: 1882, s. 4; J. Krupa, Zapiski briologiczne, SKF XVI: 1882, s. 170-204.

26 SKF 21: 1887, s. 5. 
skach suchszych mchu Myurella julacea (Schwägrichen), właściwego dla wyższych krain górskich. Nowym dla Tatr był odkryty na Żeleźnicy drąstewniczek zmienny Lescuraea striata (Schwägr.) Schimp = Lescuraea mutabilis (Bird.) Hagen ${ }^{27}$.

W dalszych latach natomiast Żmuda donosił o odkryciu nowego dla Tatr gatunku mszaka należącego do rodziny bezlistowatych: bezlistu okrywowego (Buxbaumii indusiata $=$ Buxbaumii viridis Moug. ex Lam. \& DC. $)^{28}$. Duże znaczenie miała ponadto jego praca dotycząca mchów jaskiń tatrzańskich ${ }^{29}$. Wcześniej tylko Tytus Chałubiński podał informacje o kilku gatunkach mchów w jaskiniach $\operatorname{Tatr}^{30}$. Żmuda badał jaskinie w 1912 i 1913 r., nadto w r. 1913 zebrał dla porównania materiał w Jaskini Łokietka w Ojcowie oraz zbadał kilka jaskiń Krasu w Istrii. Jak zauważył, wśród roślin wyższych $\mathrm{w}$ tatrzańskich jaskiniach nie występowały konflikty międzygatunkowe. Nieliczne pojawiające się tam gatunki mogły zasiedlać znaczne przestrzenie. W porównaniu do flory jaskiń środkowo-europejskich, ta $\mathrm{z}$ tatrzańskich był o wiele bogatsza. Ze zbadanych 21 jaskiń podał 208 gatunków roślin: 116 mchów, 66 dwuliściennych, 14 jednoliściennych ${ }^{31}$, 4 paproci, 4 wątrobowców, 3 porostów, jeden gatunek glonu.

Florą tatrzańskich wątrobowców (Marchantiophyta syn. Hepaticophyta) zajmowała się Flora Lilienfeldówna, przytaczając 48 gatunków z tego pasma ${ }^{32}$. W pracy podała rozmieszczenie kolejnych 19 gatunków, w tym dwa nowe stanowiska Scapania subalpina (Nees. ex Lindenb.) Dum. nad Czarnym Stawem pod Rysami i Scapania helvetica Gott. na hali na Kalatówkach. Jej badania terenowe w lecie i jesieni 1912 r. były bardzo utrudnione z powodu praktycznie ciągłych opadów deszczu, stąd „mała liczba wycieczek połączonych z wielkimi trudnościami”33.

\section{LICHENOLOGIA}

W 1877 r. Komisja Fizjograficzna poleciła Janocie i Rehmanowi badania flory Tatr, temu ostatniemu szczególnie porostów (Lichenes) ${ }^{34}$, po polskiej stronie Tatr

27 J. Krupa, Zapiski briologiczne z Tatr i Przedtatrza, SKF XXI: 1887, s. 65, całość tekstu s. 6594. Por.: RAU 1886, Kraków 1887, s. 106.

${ }^{28}$ SKF 46: 1911, s. X.

29 A. J. Żmuda, O roślinności jaskiń tatrzańskich, RWMP 55: 1916, ser. B, s. 147-244.

${ }^{30}$ T. Chałubiński, Enumeratio Muscorum fronelos tatrensium, „Pamiętnik Fizjograficzny” 6: 1886, s. 3-208.

${ }^{31}$ Dwuliścienne - wyróżniany dawniej takson obejmujący wszystkie rośliny okrytonasienne (okrytozalążkowe), z wyjątkiem jednoliściennych. Jednoliścienne - grupa roślin okrytonasiennych (okrytozalążkowych) o różnej randze systematycznej w zależności od systemu klasyfikacyjnego. Obecnie klad (grupa monofiletyczna).

${ }^{32}$ F. Lilien feldówna, Hepeticae Poloniae exiccatae (II. Nr 51-100), SKF XLVIII: 1913, s. 51-58.

${ }^{33}$ F. Lilienfeldówna, Przyczynek do znajomości krajowych wątrobowców, SKF XLVIII: 1913, s. 59, całość tekstu s. 59-63.

${ }^{34}$ Porosty jako samodzielna jednostka taksonomiczna przestała istnieć w 1981 roku w wyniku zmian wprowadzonych przez Międzynarodowy Kodeks Nomenklatury Botanicznej. Pojęcie to ujmowane jest obecnie w kategoriach ekologicznych, a nie systematycznych. Systematyka i nomenklatura porostów dotyczy ich komponentu grzybowego. 
„jako zupełnie prawie przez innych botaników pod tym względem zaniedbanych" 35 . Rehman wkrótce po zakończeniu badań przekazał Komisji duży ich zbiór. Józef Rostafiński przesłał je do uczonych zagranicznych celem oznaczenia. Jednakże żaden z systematyków nie podjął się zadania, stąd po kilku miesiącach opóźnienia Rehman sam zajął się ich oznaczeniem ${ }^{36}$. Uczony kontynuował badania rok później w sierpniu w Tatrach i październiku w Pieninach. Po opracowaniu zbioru złożył Komisji dwie prace ${ }^{37}$. Systematyczny spis to jedna z pierwszych prac botanicznych o Tatrach Bielskich. Rehman podał 330 gatunków, jednakże nie wszystkie stanowiska oznaczył ${ }^{38}$. Przekazał także informacje o węgierskim botaniku Hugonie Loyka (Lojka, Loika, Łojka), który w r. 1865 badał porosty w okolicach Krakowa, trzy lata później w Tatrach i powtórnie w tym paśmie w 1872 r. Z polecenia Rehmana Komisja udzieliła zasiłku Loyce na badania lichenologiczne w zachodniej Galicji ${ }^{39}$, „lecz dotąd ani sprawozdania, ani okazów nie otrzymała” (tj. do 1879 r.) ${ }^{40}$. Kolejne gatunki, m.in. z Tatr, Rehman opisał w artykule dotyczącym mchów zachodniej Galicji ${ }^{41}$.

Porostami zajmował się także Władysław Boberski. W kilku pracach poświęconych tej tematyce, a obejmującej tereny ówczesnej Galicji, zaprezentował m.in. 30 gatunków pochodzących z Tatr. W oznaczaniu poszczególnych gatunków dużą pomocą służył mu austriacki lichenolog Aleksander Zahlbruckner, botanik ksiądz Pius Strasser oraz niemiecki botanik i lichenolog z Berlina Paul Sydow ${ }^{42}$.

W 1909 r. G. Malinowski badał w Tatrach porosty skalne pod względem fizjograficznym i ekologicznym, zbierając 200 gatunków $^{43}$.

\section{MYKOLOGIA $^{44}$}

W roku 1886 Krupa miał zająć się badaniami botanicznymi Czarnohory, jednak nie najlepszy stan zdrowia sprawił, że Komisja Fizjograficzna zmieniła mu teren eksploracji naukowej na łatwiej dostępne Podhale i Tatry ${ }^{45}$. Prowadził prace

${ }^{35}$ SKF 13: 1879 , s. 6.

${ }^{36}$ SKF 12: 1878 , s. 6.

37 SKF 13: 1879, s. 4.

${ }^{38}$ A. Rehman, Systematyczny spis porostów znalezionych dotad w Galicyi zachodniej, opracowany na podstawie własnych i cudzych spostrzeżeń, SKF XIII: 1879, s. 3-66; RAU 1877, Kraków 1878, s. 123; RAU 1878, Kraków 1879, s. 168.

${ }^{39}$ SKF 4: 1870, s. 5, Loyka z polecenia Komisji udał się w Tatry celem badań porostów; Sekcja Botaniczna przekazała Loyce 100 złr na badania w Tatrach: tamże, s. 27.

40 Tamże, s. 5.

${ }^{41}$ A. Rehman, Przyczynek do briologii Galicji, SKF XIII: 1879, s. (139)-(145).

${ }^{42}$ W. Boberski, Czwarty przyczynek do lichenologii Galicji, SKF XXVII: 1892, s. (157)-(169); Drugi przyczynek do flory lichenologicznej Galicyi, „Kosmos” 10: 1885, s. 68-75; Übersicht der Flachten Galiziens, "Verhandlungen Zoologisch-Botanischen Gesellschaft in Wien", 16: 1886, s. 243-286.

${ }^{43}$ SKF 45: 1910, s. X.

${ }^{44}$ W chwili obecnej grzyby (Fungi Juss) zaliczane są do odrębnego królestwa należącego do domeny jądrowców (Eucaryota), w omawianym tu okresie były zaliczane do roślin.

${ }^{45}$ SKF 21: 1887 , s. 5. 
w paśmie regli, w Dolinie Kościeliskiej, Zakopanem, Jaszczurówce, lasach koło Witowa i nad Czarnym Dunajcem, na Gubałówce, w okolicach Obidowej i Poręby Wielkiej. Jako ciekawostkę, dobrze ilustrującą problemy, na jakie natrafiali uczeni prowadzący prace terenowe, można podać przykład próby odszukania przez Krupę widniejącej na mapie Karla Kummersberga góry „Niedźwiedź”. Jak pisze uczony „przybywszy jednak na miejsce, przekonałem się, że góra podobnej nazwy w tych stronach nie istnieje i że nazwa ta fikcyjna obejmuje cały obszar gór między Mszaną, Kamienicą a Kilkuszową" ${ }^{46}$. Opisał jeden gatunek śluzowca strzępek wyprostowany Arcyria cinerea Bull. (=Arcyria fulgens Nann.-Bremek; =Arcyria incarnata var. fulgens G. Lister) z Gubałowki oraz około 119 gatunków i odmian mchów, nie we wszystkich przypadkach określając jednak występowanie. W kolejnej pracy podał 33 gatunki grzybów tatrzańskich ${ }^{47}$.

Marian Raciborski donosił o 8 gatunkach rdzy (Pucciniomycetes), klasy grzybów $\mathrm{z}$ gromady podstawczaków (Basidiomycota) ${ }^{48}$ i 31 gatunkach śluzowców $\mathrm{z}$ Tatr ${ }^{49}$. Nadto informował o występowaniu na modrzewiach jednego gatunku z rodziny kustrzebkowatych (Pezizaceae $)^{50}$. W obszernym, wieloczęściowym dziele Mycoteca Polonica, podał dwa następne gatunki z Tatr ${ }^{51}$.

Roman Gutwiński zaprezentował gatunek śluzowca ${ }^{52} \mathrm{z}$ Tatr Arcyrella nutans Bull. $^{53}$

Adam Wodziczko przedstawił spis śluzowców i grzybów zebranych głównie na Podkarpaciu w okolicach Jasła i Rabki, ponadto koło Kosowa (Karpaty Wschodnie), w Beskidzie Niskim, Sądeckim, w Tatrach i okolicach Krakowa ${ }^{54}$. Okazy z Tatr pochodziły od Żmudy. Ogółem zaprezentowano 250 gatunków, w przeważającej części odnoszących się do terenów mało dotąd pod względem mykologicznym poznanych w Galicji. Niektóre gatunki opisano jako nowe dla Galicji. Z Tatr przytoczono 7 gatunków.

46 J. Krupa, Zapiski mykologiczne z okolic Lwowa i z Podtatrza, SKF 22: 1888, s. 12, całość tekstu: s. $12-47$.

${ }^{47}$ J. Krupa, Zapiski mykologiczne przeważnie z okolic Lwowa i z Tatr, „Kosmos” 11: 1866, s. $370-399$.

${ }^{48}$ M. Raciborski, Materiały do flory grzybów Polski. I. Rdze (Uredineae), SKF 21: 1887, s. 4964; RAU 1887, Kraków 1888, s. 98.

${ }^{49}$ M. Raciborski, Myxomyceten der Tatra, „Hedwigia” 24: 1885, s. 168-170; tegoż, Über einige Myxomycetes Polens, „Hedwigia” 28: 1889, s. 115-124; RAU 1890, Kraków 1891, s. 11; RAU 1891/1893, Kraków 1893, s. 75.

${ }^{50}$ M. Raciborski, Kilka słów o modrzewiu w Polsce, „Kosmos” 15: 1890, s. 488-497.

${ }^{51}$ M. Raciborski, Mycotheca Polonica. Cz. 1, „Kosmos” 34: 1909, s. 44; „Kosmos” 35: 1910, s. 80 .

52 Śluzowce (Myxomycota, Mycetozoa), zwane też śluzoroślami (Eumycetozoa), stanowią grupę liczącą około kilkuset gatunków organizmów eukariotycznych należąca do Amoebozo. Dawniej zaliczane były do grzybów, potem do protistów grzybopodobnych. $Z$ przyczyn historycznych w podręcznikach traktowana jako klasa roślin zarodnikowych, a w szczególności grzybów.

${ }^{53}$ R. Gutwiński, Materialy do flory śluzowców (Myxomycetes) Galicji, SKF XXXV: 1901, s. $73-75$.

${ }^{54}$ A. Wodziczko, Materiaty do mykologii Galicji, SKF XLV: 1910, s. 40-57. 
Bolesław Namysłowski prowadził badania nad rdzami (Uredomycetes), klasą grzybów podstawczaków, występującymi na obszarze Galicji i Bukowiny. W swej pracy podał 57 gatunków z Tatr, z czego 22 gatunki uznał za typowo górskie ${ }^{55}$.

Karpaty i Podkarpacie stały się terenem eksploracji naukowej Roupperta. Z Tatr opisał gatunek Cronartium ribiclola Fischer, sprawcę choroby rdzy wejmutkowo-porzeczkowej ${ }^{56}$ oraz Puccinia Zopfii G. Winter ${ }^{57}$. W kolejnej pracy podał 162 gatunki z Tatr ${ }^{58}$.

Grzybami tatrzańskimi zajmował się także Antoni Wróblewski. Podał gatunki zebrane w 1891 r. przez Żmudę w okolicach Krakowa, w Beskidach Zachodnich i Tatrach. Ich kolekcja znajdowała się w zbiorach Muzeum Fizjograficznego AU ${ }^{59}$. W latach 1913-1914 prowadził własne badania mykologiczne w Tatrach, Pieninach, Beskidzie Wschodnim, na Podkarpaciu, Podolu i na Roztoczu. W r. 1915 obszarem badań stały się ponownie tereny wokół Krakowa, a w 1916-1917 znowu Tatry. W r. 1918 powrócił w Pieniny i w okolice Lwowa. Lącznie zebrał 6-8 tys. okazów, należących głównie do grzybów workowcowych (Ascomycetes). Ze zbiorów tych opracował pierwszą część obejmującą glonowce (Phycomycetes): głowniowate (Ustilaginaceae), rdzawnikowate (Uredimales) i podstawkowate (Basidiomycetes). Razem podał 497 gatunków należących do 89 rodzajów. Jedna odmiana, oset łopianowaty Carduus personata (L.) Jacq., była nowa dla Tatr ${ }^{60}$.

\section{FYKOLOGIA}

Józef Rostafiński wprowadził do polskiej nomenklatury naukowej wyraz ,glony", zapożyczając go od górali. Jako jeden z pierwszych zajął się glonami naśnieżnymi w Tatrach, prowadząc badania terenowe w r. 1880 pod Cubryną i Rysami ${ }^{61}$. Z Tatrami związane są także jego prace dotyczące flory wodorostów ${ }^{62}$.

55 B. Namysłowski, Prodromus Uridinearum Galiciae et Bucoviniae. Rdze Galicji i Bukowiny, SKF 45: 1910, s. 65-146; Śluzowce i grzyby Galicji i Bukowiny, „Pamiętnik Fizyograficzny” 22: 1914, S. $1-151$.

56 K. Rouppert, Róża pęcherzykowata sosny amerykańskiej, „Sylwan” 28: 1910, nr 5, s. 224227; Róża pęcherzykowata na limbie w Tatarch, „Sylwan” 28: 1910, nr 12, s. 600-602.

57 K. Rouppert, Puccinia Zopfii Winter w Polsce, „Kosmos”36: 1911, s. 311-313.

58 K. Rouppert, Grzyby zebrane w Tatrach, Beskidzie Zachodnim i na Pogórzu, SKF 46: 1911, s. 80-100; RAU 1909/1910, Kraków 1910, s. 105.

59 A. Wróblewski, Przyczynek do znajomości grzybów Galicji, SKF LII: 1917, s. 122-127.

${ }^{60}$ A. Wróblewski, Wykaz grzybów zebranych $w$ latach 1913-1918 z Tatr, Pienin, Beskidów Wschodnich, Podkarpacia, Podola, Roztocza i innych miejscowości, SKF LV i LVI: 1920/21 i 1921/22, s. 1-50; RAU 1916/1917, Kraków 1917, s. 39.

61 J. Rostafiński, Tymczasowa wiadomość o czerwonym i żóltym śniegu w Tatrach $i$ o nowo odkrytej grupie wodorostów brunatnych w Tatrach, Kraków 1880, ss. 5, por.: RWMP 8: 1881, s. 8-13.

62 J. Rostafiński, O nowo odkrytej grupie wodorostów brunatnych znalezionej $w$ Tatrach, RWMP 8: 1881, s. 8-13; Hydrurus i jego pokrewieństwo, RWMP 10: 1883, s. 60-86; Sphaerogonium, nowy rodzaj wodorostów sinych, RWMP 10: 1883, s. 280-305; Chałubińskia, nowy rodzaj brunatnych wodorostów, RWMP 10: 1883, część sprawozdawcza, sprawozdanie z 20 listopada 1882, s. LXII. Opublikowana na łamach ,Wszechświata” 7: 1888 Szarotka miała charakter popularno-naukowy. 
Gutwiński zajmował się okrzemkami (Bacillariophyceae, Bacillariophyta, Diatomophyceae) tatrzańskimi. Sam nie prowadził prac terenowych, posłużył się zbiorem Raciborskiego, zebranym we wrześniu 1884 r., zawierającym 100 gatunków i odmian ${ }^{63}$. Jako materiał pomocniczy posłużyła praca Josepha Schumana, który badał Tatry w r. 1865 podając 205 gatunków ${ }^{64}$. Raciborski przedstawił 32 gatunki i 7 odmian nie opisanych przez Schumanna. Gutwiński z kolei przedstawił spis 41 gatunków i odmian nowych dla Tatr. Z powodu braku wystarczających badań nie można było jednak zaprezentować rozsiedlenia pionowego okrzemek tatrzańskich. Zasygnalizowano problem korelacji rozmiarów okrzemek w zależności od wysokości i temperatury ${ }^{65}$. Obszerny materiał dotyczący flory glonów tatrzańskich opublikował w 1909 r. na podstawie własnych pięcioletnich badań terenowych (1899-1903). Był to systematyczny przegląd, obejmujący 626 gatunków i 202 odmiany. 11 gatunków, 13 odmian i 18 form zostało po raz pierwszy opisanych przez autora ${ }^{66}$. Ostatnia jego praca naukowa dotyczyła flory i planktonu glonów Morskiego Oka ${ }^{67}$.

Duży wkład w badania glonów tatrzańskich wniosła Jadwiga Wołoszyńska, która m.in. podjęła się opracowania monograficznego bruzdnic (Dinoflagellata) ${ }^{68}$. Kolejne lata przyniosły dalsze badania planktonu roślinnego (fitoplankton) w Tat$\operatorname{rach}^{69}$. Jej badania miały charakter biogeograficzny i ekologiczny, skutkowały także odkryciami z zakresu anatomii glonów. Uczona opisała zarówno taksony nowe dla nauki, jak i rzadko opisywane w literaturze do czasów współczesnych. Nowe gatunki glonów podała na podstawie odkryć w jeziorach tatrzańskich: Toporowe Stawy Wyżni i Niżny oraz Staw Smreczyński. Opracowała glony żyjące w stawach i młakach tatrzańskich, zwracając szczególną uwagę na glony planktonowe, dotąd w Tatrach nie badane. Przedstawiła szczegółowe opisy gatunków żyjących w stawach tatrzańskich oraz ich biologię. W ciepłym, w znacznej części zarosłym już torfem Stawie Toporowym, znalazła kilka gatunków, niektóre z nich opisane zostały wcześniej przez G. Klebsa na Jawie. Dla kilku gatunków Staw Toporowy był zatem drugim znanym (i bardzo odległym) miejscem występowania. Równie ciepły Staw Smreczyński był, według uczonej, drugim miejscem skupiającym nowe gatunki ${ }^{70}$.

63 SKF 23: 1889, s. 4.

${ }^{64}$ J. Schumann, Die Diatomeen der Hochen Tatra. Taf. 1-4, "Verhandlungen der ZoologischBotanischen Gessellshaft in Wien" 17: 1867.

65 R. Gutwiński, Przyczynek do znajomości okrzemek tatrzańskich (Bacillariaceae tatrenses), SKF XXII: 1888, s. 138-150.

${ }^{66}$ R. Gutwiński, Flora algrum montium Tatrensium, „Bull. de l’Acad. Polonaise des Sc. et de Lett.” 1909; „Sprawozdania”. T. XIV, marzec 1909. Nr 3, s. 405-560; materiały dot. glonów tatrzańskich także [w:] Prodromus florae alga rum galiciensis, RWMP 28: 1895, s. 274-449.

${ }^{67}$ R. Gutwiński, Flora i plankton glonów Morskiego Oka, „Kosmos” 38: 1913, s. 1426-1437.

68 SKF 47: 1912, s. IX-X.

69 SKF 52: 1917, s. VIII.

70 J. Wołoszyńska, Glony stawów i młak tatrzańskich, RWMP 58: 1919, s. 315-322. Pracę tę referował J. Rostafiński na posiedzeniu Komisji Fizjograficznej 8 lipca 1918 r.: „Sprawozdania”. T. XXIII, lipiec 1918. Nr 7, s. 15. O badaniach w roku 1919: „Sprawozdania”. T. XXIII, październik 1919. Nr. 8, s. 17, por.: J. Wołoszyńska, Polnische Süsswasser Peridineen, “Bull. de 1' Acad. 
Dwa opisane przez siebie gatunki bruzdnic: Peridinium chalubinskii i Chalubinskia tatrica nazwała na cześć Tytusa Chałubińskiego. Jednak obydwie te nazwy są obecnie uważane za synonimy innych opisanych przez Wołoszyńską gatunków: Peridinium chalubinskii Wolosz. jest synonimem P. raciborskii Wolosz., a Chalubinskia tatrica Wolosz. synonimem P. Lomnickii Wolosz. W Morskim Oku odkryła nowy gatunek Gymnodinium tatricum Wolosz. W kolejnych pracach uczona podała spis i rozmieszczenie wszystkich znalezionych w Tatrach gatunków bruzdnic ${ }^{71}$. W związku z problematycznym ujęciem taksonomicznym niektórych gatunków, zwłaszcza należących do rodzin Gymnodiniaceae i Woloszynskiaceae (np. Gymnodinium tatricum Woloszyńska 1919), konieczne jest dalsze prowadzenie badań terenowych w celu odszukania taksonów zgodnych z opisami Wołoszyńskiej i przeprowadzenie szczegółowych studiów taksonomicznych w oparciu o współczesne metody morfologiczno-molekularne.

Celem badań Szyszyłowicza w latach 1879-1882 było dokładne oznaczenie i rozmieszczenie flory mchów i wątrobowców w Tatrach ${ }^{72}$. Przez pewien czas uczony prowadził badania w towarzystwie Chałubińskiego, zajmującego się mchami, Szyszyłowicz z kolei koncentrował się na wątrobowcach, w efekcie pozyskał około 2000 okazów. Przy oznaczaniu posługiwał się głównie The London catalogue of British Nosses (London 1881). W pracy przytoczył 134 gatunki, chodziło o ich geograficzne rozmieszczenie. Zauważył większą bujność flory wątrobowców po stronie północnej niż na południowych stokach Tatr, mimo braku odpowiednich warunków, i wytłumaczył to osuszającym wpływem wiatrów owiewających południowe stoki (wcześniej zwrócił na to uwagę Göran Wahlenberg ${ }^{73}$ ). W rozmieszczeniu gatunków zastosował podział na krainy botaniczne zaproponowane przez Chałubińskiego ${ }^{74}$. Podział ten różni się od stosowanego w chwili obecnej i nie jest używany. Szyszyłowicz podał dolne i górne granice zasięgu dla poszczególnych gatunków, ich morfologię, ogólną charakterystykę krain, rozmieszczenie w zależności od podłoża, podając także spis nazw i synonimów. W pracy zaprezentowano również charakterystykę wegetacji wątrobowców w Tatrach.

Polonaise des Sc. et. de Lett.”, Kraków 1915, s. 269-270; Die Algen der Tatraseen und Tümpel. I.; tamże, Kraków 1919; „Sprawozdania”. T. XXIII, lipiec 1918. Nr 7, s. 17-18.

${ }^{71}$ Prace te ukazywały się w okresie międzywojennym, nie wchodzą zatem w poruszany tu zakres chronologiczny: m.in.: J. Wołoszyńska, Glony stawów i młak tatrzańskich cz. 2: „Bull. de l’Acad. Polonaise des Sc. et de Lett. Cl. Math”. 1935; cz. 3; „Archiwum Hydrobiologii i Rybactwa” 10, 1936, cz. 4; „Acta Soc.Bot. Pol”. 16, 1939.

72 B. Szyszyłowicz, O rozmieszczeniu wątrobowców w Tatrach, SKF XIX: 1885, s. 25-125: RAU 1883, Kraków 1884, s. 87, o pracach Kotuli i Szyszyłowicza pisano: „obydwaj zaszczytnie znani badacze zebrali bogaty dla Komisyi materiał i zajęci są od kilku lat jego opracowaniem. Spodziewa się Komisyja otrzymać od nich wkrótce prace pod każdym względem rzecz wyczerpujące"; RAU 1884, Kraków 1885, s. 97.

${ }^{73}$ G. Wahlenberg, Flora Carpathorum principalium exibens plantarum, Göttingae 1814.

${ }^{74}$ T. Chałubiński, Grimmiae tatrensis, Varsoviae 1882, odb. z II tomu „Pamiętnika Fizyograficznego". 


\section{SPOSTRZEŻENIA FITOFENOLOGICZNE}

W pierwszych rocznikach SKF Józef Dura, proboszcz z Poronina, publikował wyniki spostrzeżeń fenologicznych z Poronina ${ }^{75}$. Jego pracę kontynuował na Podhalu ks. Wojciech Roszek ${ }^{76}$.

\section{PATOLOGIA ROŚLIN}

Z zakresu patologii roślin, o zoocecidiach, czyli galasówkach (naroślach wywołanych na roślinach przez zwierzęta pasożytnicze, głównie owady) pisał Żmuda, podając 41 przykładów z Tatr. Opisał zmiany w budowie wewnętrznej i zewnętrznej obserwowane u roślin, uniemożliwiające im normalny rozwój, m.in. przez zmiany asymilacyjne i deformacje kwiatów i łodyg ${ }^{77}$.

\section{BIOLOGIA ROŚLIN}

Wodziczko zaprezentował szafran tatrzański (szafran spiski Crocus scepusiensis (Rehm. et Woł.) gatunku należącego do rodziny kosaćcowatych (Iridaceae) ${ }^{78}$.

\section{GROMADZENIE ZBIORÓW}

Praktycznie przez cały omawiany tu okres Komisja Fizjograficzna i jej muzeum wzbogacały się o bardzo liczne okazy florystyczne, przekazywane bądź w formie darów, bądź jako wyniki badań terenowych. Przykładowo w 1869 r. informowano o zbiorze roślin z Tatr i Babiej Góry przekazanych przez Janotę, z kolei nauczyciel Edward Dudziński złożył podobny zbiór z nowotarskiego ${ }^{79}$. Od początków lipca do 12 września 1878 r. Rogalski i Szyszyłowicz badali florę północno-wschodniej części Tatr w okolicach Hawrania oraz Murania i zebrali ponad 300 gatunków roślin, ich zbiór przekazali Komisji. Krupa przekazał zbiór mchów i wątrobowców tatrzańskich, liczący 310 gatunków $^{80}$, po badaniach terenowych Kotula złożył zielnik ${ }^{81}$. W r. 1892 Komisja wzbogaciła się o zbiór wodorostów tatrzańskich, przekazanych

${ }^{75}$ J. Dura, Niektóre spostrzė̇enia meteorologiczne i pojawów w świecie roślinnym, poczynione $w$ Poroninie i na Podtatrzu Nowotarskim, SKF 1: 1867, s. [207]-[208]; Spostrzeżenia fenologiczne w Poroninie poczynione w r. 1868, SKF 3: 1869, s. [251]-[252]; Spostrzeżenia fenologiczne w Poroninie poczynione w r. 1869, SKF 4: 1870, s. [228].

${ }^{76}$ W. Roszek, Zapiski fitofenologiczne poczynione $w$ Poroninie $w r$. 1872, SKF VII: 1873, s. 166; Zapiski fitofenologiczne poczynione w Poroninie w $r$. 1873, SKF VIII: 1874, s. 162; Zapiski fitofenologiczne poczynione w Poroninie w r. 1874, SKF IX: 1875, s. 173; Zapiski fitofenologiczne poczynione $w$ Poroninie $w$ r. 1875, SKF X: 1876, s. 172.

77 A. J. Ż̇uda, Zoocecidia roślin krajowych, SKF XLVII: 1912, s. 12-40.

${ }^{78}$ A. Wodziczko, Z biologii szafranu tatrzańskiego (Crocus babiogorensis Zapatowicz), „Kosmos" 38: 1913, s. 1181-1183.

${ }^{79}$ SKF 3: 1869, s. 4.

${ }^{80}$ SKF 13: 1879, s. 8, także SKF 21: 1887, s. 5 i 9.

${ }^{81}$ SKF 23: 1889, s. 5. 
przez Rostafińskiego ${ }^{82}$. Walenty Augustynowicz badał porosty w Tatrach, głównie na ich stokach północnych, skompletowany zbiór liczący około 100 gatunków przekazał Sekcji Botanicznej ${ }^{83}$. Prof. W. Rother przekazał w darze 5 rzadkich gatunków roślin z Tatr i Zakopanego ${ }^{84}$.

Prace botaniczne, choć w mniejszym zakresie, były kontynuowane w okresie I wojny światowej ${ }^{85}$, a później prowadzone na szeroka skalę w dwudziestoleciu międzywojennym.

\section{PODSUMOWANIE}

Do roku 1918 Towarzystwo Naukowe Krakowskie, przekształcone w r. 1872 w Akademię Umiejętności, prowadziło szeroko zakrojone prace botaniczne w Tatrach. Największe zasługi na tym polu wniosła Komisja Fizjograficzna i jej Sekcja Botaniczna. Uczeni zajmowali się badaniami zarówno terenowymi, nierzadko w bardzo ciężkich warunkach, jak też i opracowywali zbiory. Koncentrowano się na zagadnieniach związanych m.in. z florystyką, briologią, lichenologią i mykologią, przez kilka lat prowadzono obserwacje fitofenologiczne. Dzięki uczonym i prywatnym ofiarodawcom znacząco wzbogaciły się botaniczne zbiory muzealne Akademii. Dorobek krakowskiego ośrodka naukowego jest bardzo poważny, wnosi znaczący wkład w dzieło naukowego zbadania Tatr pod względem botanicznym. Prace $\mathrm{z}$ zakresu botaniki były prowadzone jeszcze w szerszym zakresie w okresie dwudziestolecia międzywojennego.

JANUSZ M. ŚLUSARCZYK

THE CRACOW SCIENTIFIC SOCIETY AND THE POLISH ACADEMY OF ARTS AND SCIENCES IN THE BOTANIC STUDIES IN THE TATRA MOUNTAINS UNTIL 1914

Summary

The botanic studies carried out in the Tatra Mountains, especially on the northern slopes situated on the Polish side of this mountain range, inspired by the Cracow Scientific Society, and later by the Polish Academy of Arts and Sciences, impress with their size and thematic range. This issue should become a subject matter of an extensive monograph, even if it would be for the contribution of both Cracow institutions into the work of scientific exploration of the highest range of the Carpathian Mountains. The present article provides a historical outline of these issues but does not exhaust the topic. The content of the article is arranged according to the subject matter and chronology.

${ }^{82}$ SKF 27: 1892, s. 6.

${ }^{83}$ SKF 47: 1912, s. IX; SKF 48: 1913, s. X i XIV.

${ }^{84}$ Tamże, s. XIV.

${ }^{85}$ J. M. Ślusarczyk, Działalność Komisji Fizjograficznej Akademii Umiejętności w latach I wojny światowej, „Roczniki Biblioteki Naukowej PAU i PAN w Krakowie”. R. 59, Kraków 2014, s. $127-137$. 
The biggest contribution was made by the Physiographic Committee and its Botanic Section. The scientists carried out field research, often in very hard conditions, and compiled the collection. They concentrated on the issues connected with, inter alia, floristics, bryology, lichenology and mycology, through several years phytophenological observations were carried out. Thanks to the scientists and private donors, the botanic collection of the Cracow Scientific Society was considerably enriched and later passed by the Society to the museum collection of the Academy. 